\title{
Resource partitioning among sympatric elasmobranchs in the central-western Mediterranean continental shelf
}

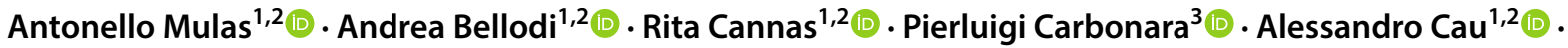

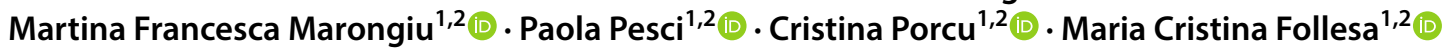

Received: 21 December 2018 / Accepted: 12 October 2019

(c) Springer-Verlag GmbH Germany, part of Springer Nature 2019

\begin{abstract}
Knowledge of the mechanisms that allow coexistence among sympatric species is fundamental to understand ecosystem functioning. Resource partitioning among seven elasmobranchs inhabiting the Sardinian continental shelf $\left(40^{\circ} 07^{\prime} \mathrm{N}, 9^{\circ} 00^{\prime} \mathrm{E}\right)$ : Dasyatis pastinaca; Raja asterias; $R$. brachyura; $R$. clavata; $R$. miraletus; $R$. polystigma and Scyliorhinus canicula, was investigated through stomach content analysis. Data from 1680 samples collected between 2005 and 2014, in 26-200 m depth, were analysed with respect to population, sex, season (winter and summer) and size groups. Species living in shallower waters (characterized by a narrower bathymetric range) had the most specialized diets. All species appeared to be mesopredators, feeding mainly on Crustacea, Actinopterygii, Mollusca and Polychaeta. Despite shared common morphological features, from the high ecological diversity of prey items, we hypothesized the presence of different predatory behavior among the species studied: some species were able to feed on endobenthic and/or epibenthic organisms, while others had made limited movements in the water column. Non-parametric Multi-Dimensional Scaling analysis highlighted the presence of five predator groups, confirming strong resource partitioning, as also demonstrated by low levels of interspecific niche overlap. The observed variations in feeding habits could be ascribed only to size and not to sex or season. Generally, diet changed from small Crustacean prey, to larger prey, like Actinopterygii and Mollusca. Some species became more generalist during development, others restricted their prey range. Shifts in feeding habits affected species' roles in the food web, with different species occupying different functional trophic groups over the course of their life cycles.
\end{abstract}

\section{Introduction}

Knowledge of marine species' trophic ecology, such as the range of prey consumed, trophic level, ontogenetic changes

Responsible Editor: E. Hunter.

Reviewed by Undisclosed experts.

Electronic supplementary material The online version of this article (https://doi.org/10.1007/s00227-019-3607-0) contains supplementary material, which is available to authorized users.

Antonello Mulas

amulas@unica.it

1 Department of Life and Environmental Sciences, University of Cagliari, Via T. Fiorelli, 1, 09126 Cagliari, Italy

2 CoNISMa, Consorzio Interuniversitario per le Scienze del Mare, Piazzale Flaminio, 9, 00196 Rome, Italy

3 COISPA Tecnologia \& Ricerca, Stazione Sperimentale per lo Studio delle Risorse del Mare, Via dei Trulli 18/20, 70126 Bari, Italy in diet, especially at a multispecific level, play an increasing important role in the development of new fisheries management strategies. Unfortunately, most of the literature on trophic interactions, especially in the Mediterranean, usually focuses on the diet comparison of just two or three species (Valls et al. 2011, 2017; Barría et al. 2015, 2018). More complex studies are limited to a few papers, published in recent decades and focusing on the main predator groups, like bony fishes (Cabral et al. 2002; Valls et al. 2014b; Karachle 2017; Park et al. 2017; Paul et al. 2018), elasmobranchs (Orlov 1998; Valls et al. 2011; Barría et al. 2015, 2018; Kousteni et al. 2018), cetaceans (Liu et al. 2015) and cephalopods (Cherel et al. 2009), while studies on betweentaxa interactions are even fewer (Valls et al. 2014a, 2017). Concentration on large predator groups is driven by the predators roles in the food chain, i.e. regulating the abundance and dynamics of lower level prey populations, through mechanisms including top-down control (Ferretti et al. 2010; Heithaus et al. 2012). Indeed, decades of ecological research have shown that changes in predator abundance can generate long-term consequences on the functionality and resilience 
of ecosystem structure (Paine 1969; Beddington 1984; Duffy 2002).

In this context, Elasmobranchs are important predators, occupying the highest levels of marine food chains (Cortés 1999; Ebert and Bizzarro 2007; Jacobsen and Bennett 2013; Barría et al. 2015). Their K-selected biological features make them vulnerable to exploitation (Stevens et al. 2000), so their management and preservation is a matter of priority (Dulvy et al. 2014, 2017). Knowledge of their life cycles and the roles they play in marine ecosystems are often fragmented, so predicting the consequences of declining population levels is difficult (Ferretti et al. 2010; Heithaus et al. 2012; Navia et al. 2016). A fundamental aspect of the trophic ecology of all predators is the degree of specialization in their diets. Species with a narrow trophic niche affect only a small number of prey, while generalist feeders can exploit a wider range of prey (Wetherbee et al. 1990; Irschick et al. 2005; Colles et al. 2009; Navarro et al. 2013). Moreover, from an intra-specific perspective, prey type and range can vary among subgroups, e.g. alimentary changes during growth or between sexes among many elasmobranchs (Wetherbee et al. 2012). Such behaviours minimize competition and guarantee higher survival rates during sensitive life stages, e.g. juveniles (Matich et al. 2017). Similarly, at an interspecific level, more variability of the alimentary spectrum could allow broader coexistence of different species without an associated phenotypic selection for the exploitation of different prey items or in case of a sudden lack of resources that could increase competition (Sánchez-Hernández et al. 2011). Improving the knowledge-base of resource partitioning seems, therefore, crucial, for sympatric species (Valls et al. 2011).

At a global level, the Mediterranean ecoregions are amongst the most impacted by human activities (Katsanevakis et al. 2014). The continental shelf (0-200 m depth) is affected by both sea-based and land-based drivers (Micheli et al. 2013). Because the analysis of the conservation status of Mediterranean elasmobranch species has revealed the area as a hotspot of extinction risk (Dulvy et al. 2014), including some endemic species, like Leucoraja melitensis, Raja polystigma and $R$. radula (Frodella et al. 2016; Dulvy et al. 2016), the need for more data is clear.

Our work aims to analyse the trophic ecology and the resource partitioning among seven sympatric elasmobranch species inhabiting the Sardinian continental shelf (centralwestern Mediterranean) (Marongiu et al. 2017). Since these species exploit the same habitats, we hypothesized that strong resource partitioning facilitates coexistence, minimizing trophic niche overlap. Following analysis of stomach content data, we studied the prey range, trophic niche breadth, trophic level and different predatory behaviours of our target populations. We examined how ontogenetic changes, sex and season may affect intra- and inter-specific interactions, highlighting the roles that these species have in the food webs over the duration of their life cycles, providing a useful tool for the implementation of management measures.

\section{Materials and methods}

\section{Data sampling}

We analysed a total of 1680 stomachs, belonging to seven elasmobranch species: Dasyatis pastinaca (Myliobatiformes, Dasyatidae), Raja asterias, $R$. brachyura, $R$. clavata, $R$. miraletus, $R$. polystigma (Rajiformes, Rajidae) and Scyliorhinus canicula (Carcharhiniformes, Scyliorhinidae). Samples were collected around Sardinia (central-western Mediterranean) (Fig. 1) at depths between 26 and $200 \mathrm{~m}$, in the period 2005-2014, during the MEDITS (MEDiterranean International Trawl Survey) and GRUND (GRUppo Nazionale risorse Demersali) experimental trawl surveys, carried out, respectively, in summer and winter, and during commercial hauls, conducted in both summer and winter. Specimens were measured (Total Length, TL in mm, Table 1) and sex and maturity stages were determined through the scales provided by the MED.I.T.S. protocol (MEDITS, Handbook 2016).

\section{Stomach content analysis}

Stomachs were dissected on board and stored in a 5\% formaldehyde solution. Prey items were identified to the lowest taxonomic level possible, counted, dried on tissue paper and weighed. Taxonomic nomenclature followed the most recent World Register of Marine Species (WoRMS Editorial Board 2018), except for the "shrimps group", for which the traditional subdivision in Decapoda Natantia and Decapoda Reptantia was preferred, as this better expressed the prey's ecological characteristics.

Cumulative prey curves (Ferry and Cailliet 1996) were built using the EstimateS software (Version 8.2, R. K. Colwell 2009, http://purl.oclc.org/estimates) to verify the sample size sufficiency. Following Brown et al. (2012), the slope of the linear regression (b) through the last five subsamples was used: $b \leq 0.05$ signified an acceptable levelling off of the prey curve for diet characterization. The Vacuity Coefficient $(\% \mathrm{CV})$ was calculated as the percentage number of empty stomachs with respect to the total number of collected stomachs (Hyslop 1980). The percentage Prey Specific Index of Relative Importance (\%PSIRI) (Brown et al. 2012), a modification of the classical percentage Index of Relative Importance (\%IRI), was adopted to assess the 


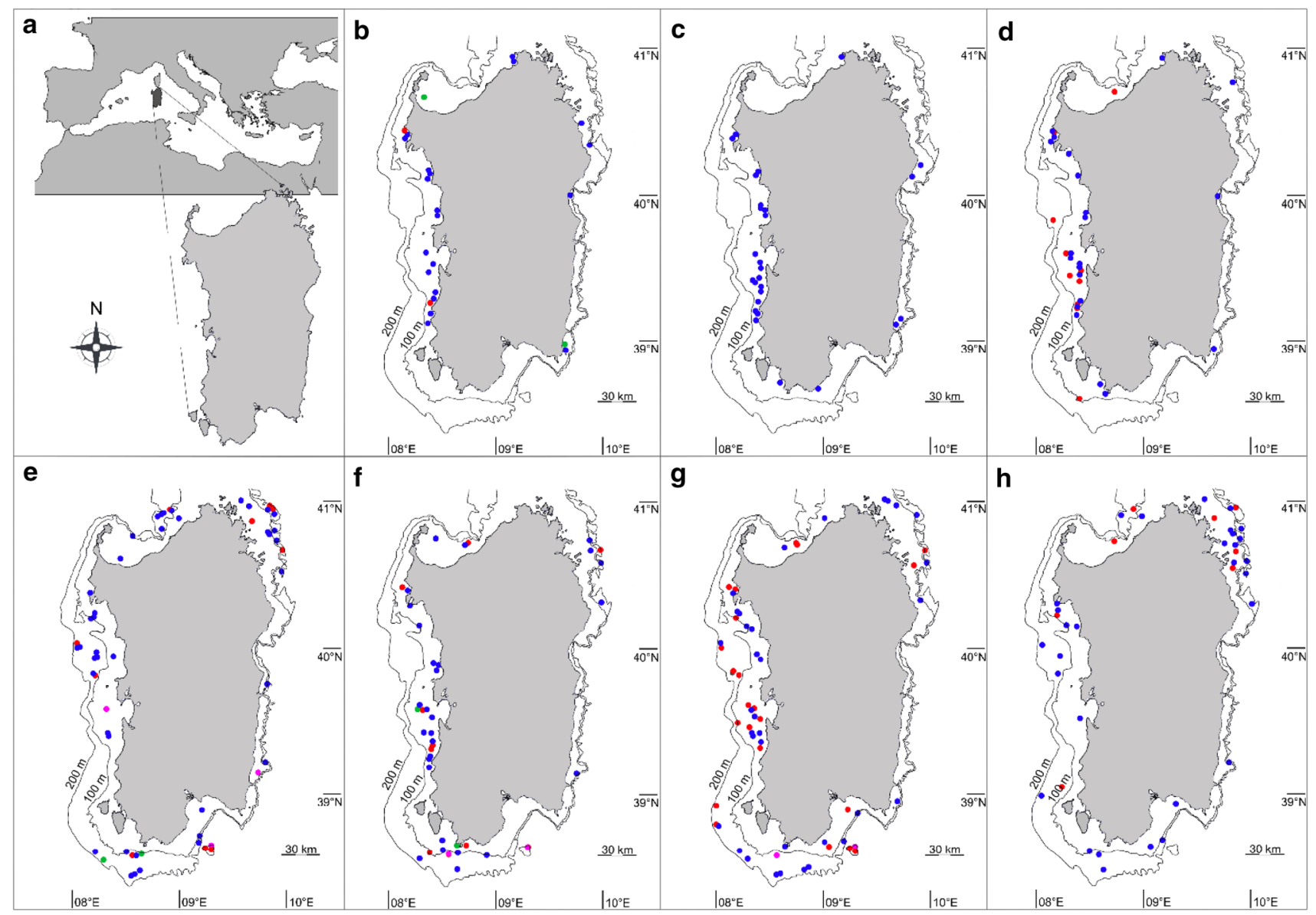

Fig. 1 Investigated area (a) and sampling sites for: b Dasyatis pastinaca; c Raja asterias; d Raja brachyura; e Raja clavata; f Raja miraletus; $\mathbf{g}$ Raja polystigma; $\mathbf{h}$ Scyliorhinus canicula ( $\bullet=$ samples

contribution of each prey item to the diet according to the formula: $\%$ PSIRI $=\frac{\left[\% \mathrm{FO}_{\mathrm{i}} *\left(\% \mathrm{PN}_{\mathrm{i}}+\% \mathrm{PW}_{\mathrm{i}}\right)\right]}{2}$, where $\% \mathrm{FO}_{i}$ is the percent Frequency of Occurrence of an item in all samples; $\% \mathrm{PN}_{\mathrm{i}}$ and $\% \mathrm{PW}_{\mathrm{i}}$ represent the prey specific abundances in terms of number and weight as a modification of IRI's $\% \mathrm{~N}$ (prey percent number) and $\% W$ (prey percent weight). One of the benefits given by the \%PSIRI is that it is additive with respect to taxonomic levels (Brown et al. 2012).

\section{Diet comparison among size groups, sexes and seasons}

To study possible ontogenetic changes in alimentary behaviour, three size groups were identified for each predator species, dependent on the maturity stage: juveniles (immature at stage 1) were the smallest, subadults (maturing at stage 2 ), were intermediate in size, and adults (mature and resting at stages 3 and 4) were the largest (Table 1). Size groups were labeled with the initial letters of the species' name and a progressive number ( 1 =juveniles, 2 =subadults, $3=$ adults $)($ Table 1$)$. collected during MEDITS; $=$ samples collected during GRUND; - = samples collected during summer commercial hauls; 0 samples collected during winter commercial hauls)

Diet was further analysed with respect to sex and season (winter and summer), except for $R$. asterias, which was caught only during summer (Table 1).

\section{Trophic niche breadth and trophic niche overlap}

To measure the trophic niche breadth, the Levins' index $\left(B_{i}\right)$ (Levins 1968) was calculated, using the formula: $B_{i}=\left(\frac{1}{n-1}\right) \times\left(\frac{1}{\sum_{j} p_{i j}^{2}}\right)$, where $\mathrm{n}$ is the number of prey categories and $p_{i j}$ is the proportion of the prey $j$ in the diet of the species $i$. The Morisita's index $\left(C_{\mathrm{h}}\right)($ Krebs 1989; Hall et al. 1990) was used to examine the levels of intra- and interspecific trophic niche overlap, following the equation: $C_{\mathrm{h}}=\frac{2 \sum_{k}\left(p_{i k} * p_{j k}\right)}{\sum_{k} p_{i k}^{2}+\sum_{k} p_{j k}^{2}}$, where $p_{i k}$ is the proportion of the prey $k$ in the diet of the group $i$ and $p_{j k}$ is the proportion of the prey $k$ in the diet of the group $j$. 
Table 1 Samples characteristics of the seven analysed species: total length (TL, in $\mathrm{mm}$ ), total number of analysed stomachs $(N)$, Coefficient of Vacuity $(\% \mathrm{CV}$ ) and depth range (in $\mathrm{m}$ ) of the overall populations and subgroups

\begin{tabular}{|c|c|c|c|c|c|}
\hline Species & Group & $\mathrm{TL}(\mathrm{mm})$ & $N$ & $\% \mathrm{CV}$ & Depth range $(\mathrm{m})$ \\
\hline \multirow[t]{8}{*}{ D. pastinaca } & Overall & $181-721$ & 229 & 8.73 & \multirow[t]{8}{*}{$28-65$} \\
\hline & DP1 & $<400$ & 89 & 4.49 & \\
\hline & DP2 & $400-500$ & 96 & 10.52 & \\
\hline & DP3 & $>500$ & 44 & 13.64 & \\
\hline & Females & $181-721$ & 114 & 8.77 & \\
\hline & Males & $286-672$ & 115 & 8.70 & \\
\hline & Summer & 279-685 & 151 & 11.26 & \\
\hline & Winter & $181-721$ & 78 & 3.85 & \\
\hline \multirow[t]{8}{*}{ R. asterias } & Overall & $195-689$ & 233 & 14.16 & \multirow[t]{8}{*}{$26-78$} \\
\hline & RA1 & $<450$ & 54 & 18.52 & \\
\hline & RA2 & $450-550$ & 79 & 18.99 & \\
\hline & RA3 & $>550$ & 100 & 8.00 & \\
\hline & Females & $210-689$ & 134 & 6.72 & \\
\hline & Males & $195-622$ & 99 & 24.24 & \\
\hline & Summer & $195-689$ & 233 & 14.16 & \\
\hline & Winter & - & - & - & \\
\hline \multirow[t]{8}{*}{ R. brachyura } & Overall & $173-1000$ & 250 & 16.80 & \multirow[t]{8}{*}{$26-162$} \\
\hline & RB1 & $<400$ & 148 & 20.33 & \\
\hline & RB2 & $400-800$ & 60 & 15.38 & \\
\hline & RB3 & $>800$ & 42 & 27.27 & \\
\hline & Females & $173-1000$ & 121 & 19.83 & \\
\hline & Males & $176-965$ & 129 & 16.22 & \\
\hline & Summer & $176-1000$ & 145 & 18.62 & \\
\hline & Winter & $173-879$ & 105 & 14.29 & \\
\hline \multirow[t]{8}{*}{ R. clavata } & Overall & $129-900$ & 220 & 3.64 & \multirow[t]{8}{*}{ 26-200 } \\
\hline & $\mathrm{RC} 1$ & $<350$ & 43 & 4.65 & \\
\hline & $\mathrm{RC} 2$ & $350-550$ & 93 & 5.38 & \\
\hline & $\mathrm{RC} 3$ & $>550$ & 84 & 1.19 & \\
\hline & Females & $185-900$ & 120 & 4.17 & \\
\hline & Males & $129-770$ & 100 & 3.00 & \\
\hline & Summer & $129-900$ & 128 & 5.47 & \\
\hline & Winter & $187-843$ & 92 & 1.09 & \\
\hline \multirow[t]{8}{*}{ R. miraletus } & Overall & $94-492$ & 276 & 3.99 & \multirow[t]{8}{*}{$30-176$} \\
\hline & RM1 & $<300$ & 111 & 3.60 & \\
\hline & RM2 & $300-400$ & 104 & 3.85 & \\
\hline & RM3 & $>400$ & 61 & 4.92 & \\
\hline & Females & $115-492$ & 139 & 3.60 & \\
\hline & Males & $94-489$ & 137 & 4.38 & \\
\hline & Summer & $141-492$ & 195 & 3.59 & \\
\hline & Winter & $94-472$ & 81 & 4.94 & \\
\hline
\end{tabular}

Table 1 (continued)

\begin{tabular}{llllll}
\hline Species & Group & TL $(\mathrm{mm})$ & $N$ & $\% \mathrm{CV}$ & Depth range $(\mathrm{m})$ \\
\hline R. polystigma & Overall & $140-785$ & 254 & 5.12 & $36-190$ \\
& RP1 & $<300$ & 86 & 3.49 & \\
& RP2 & $300-400$ & 96 & 4.17 & \\
& RP3 & $>400$ & 72 & 8.33 & \\
& Females & $104-785$ & 127 & 4.72 & \\
& Males & $125-585$ & 127 & 5.51 & \\
& Summer & $179-590$ & 145 & 2.76 & \\
S. canicula & Winter & $104-785$ & 109 & 8.26 & \\
& Overall & $174-500$ & 218 & 16.51 & $30-200$ \\
& SC1 & $<250$ & 34 & 2.94 & \\
& SC2 & $250-400$ & 76 & 11.84 & \\
& SC3 & $>400$ & 108 & 24.07 & \\
& Females & $186-500$ & 107 & 14.95 & \\
& Males & $174-492$ & 111 & 18.02 & \\
& Summer & $174-500$ & 152 & 20.39 & \\
& Winter & $184-472$ & 66 & 7.58 & \\
\hline
\end{tabular}

\section{Trophic level}

The trophic level (TROPH) was defined for species and size groups, sexes and seasons, according to the formula proposed by Pauly and Christensen (1995): $1+\sum_{i=1}^{n} p_{i j} * \mathrm{TROPH}_{j}$ where $\mathrm{TROPH}_{j}$ (attributed following Pauly et al. 2000) represents the fractional trophic level of the prey $j$.

According to Stergiou and Karpouzi (2002) TROPH values were used to assess the functional trophic groups of each species and sub-group as follows:

- $2.0<\mathrm{TROPH}<2.1(\mathrm{H})$ pure herbivores.

- $2.1<\mathrm{TROPH}<2.9(\mathrm{OV})$ omnivores with a preference for plants.

- $2.9<\mathrm{TROPH}<3.7(\mathrm{OA})$ omnivores with a preference for animals.

- $\quad 3.7<$ TROPH $<4.0(\mathrm{CD})$ carnivores with a preference for crustacean decapods/fish.

- $4.0<$ TROPH $<4.5$ (CC) carnivores with a preference for fish/cephalopods.

\section{Statistical analysis}

The Primer v.7 software (Clarke and Gorley 2015) was used to perform ANOSIM (ANalysis Of SIMilarities) tests, for possible statistical differences among groups' diets. The SIMPER (SIMilarity PERcentages) test was used to determine which items were primarily responsible 
for dietary differentiation and the nMDS (non-parametric Multi-Dimensional Scaling) analysis, to highlight the presence of major predator groups. The results obtained by the Morisita's index were tested through the null model analysis using the software EcoSim v.7.72 (Goetelli and Entsminger 2005). Null model analysis compares the observed dietary overlap values to a distribution of expected overlaps values constructed with a null model simulation (Bizzarro et al. 2007).

\section{Results}

Our sample sizes were sufficient to describe the speciesspecific diets for our sampled populations, size groups, sexes and seasons, as the cumulative prey curves always reached the asymptote ( $b$ values $\leq 0.05$; Tables 2,3 ).

Table 2 Sampling adequacy, trophic niche breadth and trophic level of the overall populations and size groups $(1=$ juveniles; $2=$ subadults; 3 =adults) of the analysed species: cumulative prey curves $b$ values, Levins' index $\left(B_{i}\right)$ and trophic level $(\mathrm{TROPH} \pm \mathrm{SE})$

\begin{tabular}{|c|c|c|c|c|}
\hline Species & Group & $b$ value & $B_{i}$ & $\mathrm{TROPH} \pm \mathrm{SE}$ \\
\hline \multirow[t]{4}{*}{ D. pastinaca } & Overall & 0.000 & 0.27 & $3.44 \pm 0.51$ \\
\hline & DP1 & 0.023 & 0.13 & $3.27 \pm 0.44$ \\
\hline & DP2 & 0.036 & 0.32 & $3.61 \pm 0.58$ \\
\hline & DP3 & 0.030 & 0.43 & $3.71 \pm 0.63$ \\
\hline \multirow[t]{4}{*}{ R. asterias } & Overall & 0.000 & 0.23 & $3.81 \pm 0.65$ \\
\hline & RA1 & 0.047 & 0.16 & $3.54 \pm 0.58$ \\
\hline & RA2 & 0.017 & 0.22 & $3.78 \pm 0.64$ \\
\hline & RA3 & 0.010 & 0.25 & $3.96 \pm 0.68$ \\
\hline \multirow[t]{4}{*}{ R. brachyura } & Overall & 0.005 & 0.31 & $3.83 \pm 0.65$ \\
\hline & RB1 & 0.000 & 0.58 & $3.46 \pm 0.53$ \\
\hline & $\mathrm{RB} 2$ & 0.020 & 0.07 & $4.33 \pm 0.77$ \\
\hline & RB3 & 0.003 & 0.17 & $4.42 \pm 0.76$ \\
\hline \multirow[t]{4}{*}{ R. clavata } & Overall & 0.005 & 0.44 & $3.81 \pm 0.65$ \\
\hline & $\mathrm{RC} 1$ & 0.005 & 0.55 & $3.37 \pm 0.50$ \\
\hline & $\mathrm{RC} 2$ & 0.000 & 0.44 & $3.75 \pm 0.63$ \\
\hline & $\mathrm{RC} 3$ & 0.013 & 0.24 & $4.10 \pm 0.71$ \\
\hline \multirow[t]{4}{*}{ R. miraletus } & Overall & 0.005 & 0.37 & $3.49 \pm 0.54$ \\
\hline & RM1 & 0.000 & 0.41 & $3.37 \pm 0.49$ \\
\hline & RM2 & 0.020 & 0.31 & $3.52 \pm 0.57$ \\
\hline & RM3 & 0.000 & 0.23 & $3.65 \pm 0.56$ \\
\hline \multirow[t]{4}{*}{ R. polystigma } & Overall & 0.000 & 0.45 & $3.55 \pm 0.54$ \\
\hline & $\mathrm{RP} 1$ & 0.013 & 0.33 & $3.31 \pm 0.46$ \\
\hline & $\mathrm{RP} 2$ & 0.010 & 0.48 & $3.53 \pm 0.53$ \\
\hline & RP3 & 0.015 & 0.40 & $3.88 \pm 0.65$ \\
\hline \multirow[t]{4}{*}{ S. canicula } & Overall & 0.005 & 0.44 & $3.72 \pm 0.56$ \\
\hline & $\mathrm{SC} 1$ & 0.000 & 0.85 & $3.59 \pm 0.51$ \\
\hline & $\mathrm{SC} 2$ & 0.015 & 0.51 & $3.69 \pm 0.56$ \\
\hline & SC3 & 0.000 & 0.40 & $3.79 \pm 0.58$ \\
\hline
\end{tabular}

\section{General diet description}

Population dietary characteristics of the seven analysed species are reported in Table 1. During the study, a total of 1680 stomachs was collected. Vacuity coefficient (\%CV) was quite variable (Table 1), ranging from 3.6 in Raja clavata and 16.8 in R. brachyura. Prey belonged to nine major taxonomic groups: Crustacea, Actinopterygii, Mollusca and Polychaeta were the most important, while Cephalochordata, Elasmobranchii, Cnidaria, Sipuncula and Tunicata could be considered as occasional or accidental in most of the predators' diets (Table S1). Crustacea represented the first trophic resource in almost all the examined species, reaching the highest \%PSIRI values in $R$. miraletus (89.12). Actinopterygii were the second most consumed items (Table S1) except for $R$. brachyura, which fed to a larger extent on these prey (\%PSIRI = 46.12). Mysida, Lophogastrida, Decapoda and Amphipoda were the most frequently consumed Crustacea. Mysida represented $48.11 \%$ (\%PSIRI) of the diet of Dasyatis pastinaca, and $18.13 \%$ (\%PSIRI) of that of $R$. brachyura, while Lophogastrida characterized the feeding of R. polystigma (\%PSIRI=32.51) (Table S1). Among Decapoda, Brachyura were the most important in $R$. asterias' diet (\%PSIRI =36.17), as well as Natantia in that of $R$. miraletus, Scyliorhinus canicula and $R$. clavata $(\% \mathrm{PSIRI}=38.92,15.73$ and 11.01, respectively). Anomura consumption was considerable in $S$. canicula and $R$. clavata (\%PSIRI $=14.0$ and 8.37, respectively). The highest Amphipoda \%PSIRI values were observed in $R$. miraletus (15.98), R. polystigma (14.02), R. brachyura (12.78) and D. pastinaca (11.60) (Table S1).

All studied species preyed upon Polychaeta and Cephalopoda (Table S1). Polychaeta reached maximum values of \%PSIRI in S. canicula (15.19) and R. brachyura (13.80), while Cephalopoda were more important in the diet of $S$. canicula $(\%$ PSIRI = 11.10) $($ Table S1).

\section{Resource partitioning}

An nMDS analysis (Fig. 2) highlighted the presence of five major predator groups, divided primarily on the basis of differential consumption of Crustacea (Table S1):

1. Dasyatis pastinaca and R. miraletus (high percentage of Mysida, Amphipoda and Decapoda Natantia in the diet).

2. Raja asterias (Decapoda Brachyura and Sipuncula).

3. Raja polystigma (Lophogastrida).

4. Raja clavata and S. canicula (significant presence of Decapoda Anomura, Euphausiacea and Mollusca Cephalopoda).

5. Raja brachyura (most piscivorous diet, with a particular preference for Gymnammodytes cicerelus). 
Table 3 Sampling adequacy, trophic niche breadth, trophic niche overlap and trophic level of the sexes and seasons of the analysed species: Cumulative prey curves $b$ values, Levins' index $\left(B_{i}\right)$, trophic level $(\mathrm{TROPH} \pm \mathrm{SE})$, Morisita's index $\left(C_{\mathrm{h}}\right)$ and null model analysis $p$ values

\begin{tabular}{|c|c|c|c|c|c|c|}
\hline Species & Group & $b$ value & $B_{i}$ & $\mathrm{TROPH} \pm \mathrm{SE}$ & $C_{\mathrm{h}}$ & $\begin{array}{l}\text { Null model } \\
\text { analysis ( } p \\
\text { value) }\end{array}$ \\
\hline \multirow[t]{4}{*}{ D. pastinaca } & Females & 0.020 & 0.34 & $3.47 \pm 0.53$ & 1 & 0.000 \\
\hline & Males & 0.010 & 0.24 & $3.42 \pm 0.50$ & & \\
\hline & Summer & 0.015 & 0.29 & $3.48 \pm 0.54$ & 0.97 & 0.000 \\
\hline & Winter & 0.015 & 0.23 & $3.35 \pm 0.48$ & & \\
\hline \multirow[t]{4}{*}{ R. asterias } & Females & 0.000 & 0.24 & $3.87 \pm 0.66$ & 0.89 & 0.050 \\
\hline & Males & 0.027 & 0.23 & $3.71 \pm 0.64$ & & \\
\hline & Summer & 0.000 & 0.23 & $3.81 \pm 0.65$ & - & - \\
\hline & Winter & - & - & - & & \\
\hline \multirow[t]{4}{*}{ R. brachyura } & Females & 0.010 & 0.33 & $3.81 \pm 0.63$ & 0.98 & 0.000 \\
\hline & Males & 0.000 & 0.33 & $3.84 \pm 0.65$ & & \\
\hline & Summer & 0.017 & 0.17 & $4.06 \pm 0.72$ & 0.79 & 0.002 \\
\hline & Winter & 0.013 & 0.52 & $3.52 \pm 0.53$ & & \\
\hline \multirow[t]{4}{*}{ R. clavata } & Females & 0.017 & 0.38 & $3.84 \pm 0.65$ & 0.9 & 0.002 \\
\hline & Males & 0.010 & 0.52 & $3.78 \pm 0.64$ & & \\
\hline & Summer & 0.007 & 0.37 & $3.88 \pm 0.65$ & 0.77 & 0.017 \\
\hline & Winter & 0.023 & 0.46 & $3.73 \pm 0.62$ & & \\
\hline \multirow[t]{4}{*}{ R. miraletus } & Females & 0.015 & 0.34 & $3.48 \pm 0.54$ & 0.98 & 0.000 \\
\hline & Males & 0.000 & 0.45 & $3.49 \pm 0.54$ & & \\
\hline & Summer & 0.000 & 0.42 & $3.50 \pm 0.55$ & 0.59 & 0.064 \\
\hline & Winter & 0.013 & 0.39 & $3.46 \pm 0.52$ & & \\
\hline \multirow[t]{4}{*}{ R. polystigma } & Females & 0.007 & 0.49 & $3.55 \pm 0.55$ & 1 & 0.000 \\
\hline & Males & 0.007 & 0.47 & $3.55 \pm 0.54$ & & \\
\hline & Summer & 0.007 & 0.36 & $3.55 \pm 0.54$ & 0.64 & 0.005 \\
\hline & Winter & 0.000 & 0.23 & $3.55 \pm 0.55$ & & \\
\hline \multirow[t]{4}{*}{ S. canicula } & Females & 0.000 & 0.49 & $3.76 \pm 0.58$ & 0.92 & 0.000 \\
\hline & Males & 0.010 & 0.48 & $3.67 \pm 0.54$ & & \\
\hline & Summer & 0.007 & 0.45 & $3.73 \pm 0.57$ & 0.87 & 0.000 \\
\hline & Winter & 0.000 & 0.61 & $3.69 \pm 0.53$ & & \\
\hline
\end{tabular}

\section{Trophic niche breadth and trophic level}

The width of the trophic spectrum showed modest differences among the seven species. The Levins' index $\left(B_{i}\right)$ values ranged between 0.23 in $D$. pastinaca, that could be considered as a moderately specialist species and 0.45 in $R$. polystigma, a moderately generalist species (Table 2 ).

The trophic level $(\mathrm{TROPH} \pm \mathrm{SE})$ comprised a range between $3.44 \pm 0.51$ (in D. pastinaca) and $3.83 \pm 0.65$ (in $R$. brachyura) (Table 2) with species belonging to two functional trophic groups:

(1) OA: D. pastinaca, $R$. miraletus, $R$. polystigma.

(2) CD: $R$. asterias, $R$. brachyura, $R$. clavata, S. canicula.

\section{Diet comparison among sexes and seasons}

No significant differences were found in the diets between sexes and seasons, a finding also reflected in the values of the
Morisita's index, which displayed a high degree of trophic niche overlap, confirmed by statistical analysis (Table 3 ). In the same way, neither sex nor season influenced trophic level (Table 3).

\section{Ontogenetic changes in the diet}

Vacuity coefficient per size group was very variable. The number of empty stomachs generally increased with predator size, except for $R$. asterias and $R$. clavata, which showed the opposite tendency (Table 1). Scyliorhinus canicula exhibited the widest range with a \% CV of 2.94 in juveniles, 11.84 in subadults and 24.07 in adults.

Amphipoda, Mysida and Lophogastrida represented the main food source for the juveniles of almost all species (Fig. 4; Table S2). Amphipoda (\%PSIRI = 30.49) (particularly Gammaridea) represented the main prey for $R$. miraletus juveniles (Fig. 4; Table S2). Dasyatis pastinaca and $R$. brachyura juveniles fed on Mysida (\%PSIRI $=70.03$ and 26.94, respectively) belonging mainly to the genus 


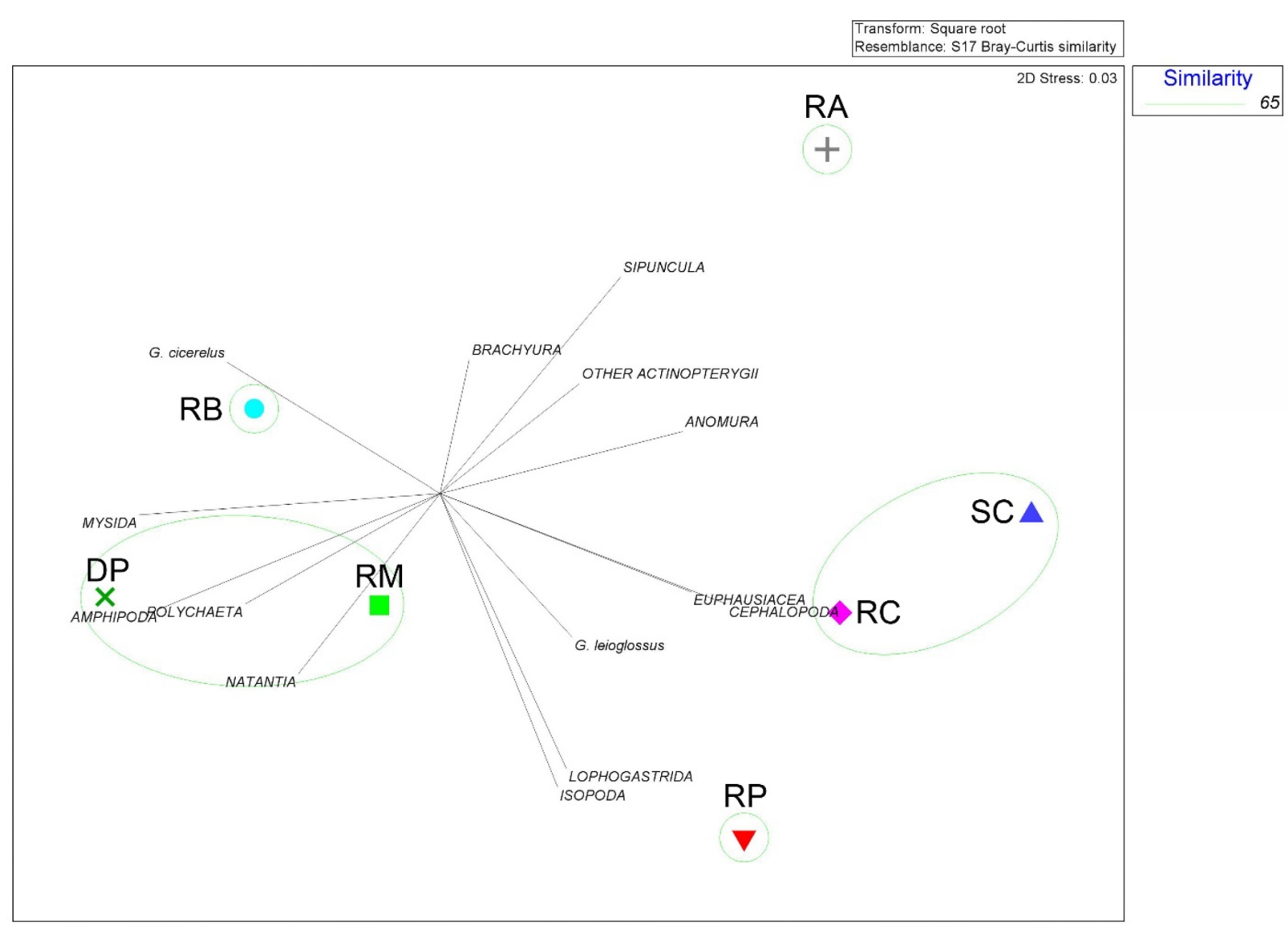

Fig. 2 Resource partitioning among the populations sampled as highlighted by the non-parametric Multi-Dimensional Scaling (nMDS) analysis for: DP Dasyatis pastinaca; RA Raja asterias; RB Raja

Gastrosaccus spp. and particularly to the species $G$. sanctus (Table S1). Raja polystigma and $R$. clavata juveniles showed a clear preference for the Lophogastrida Lophogaster typicus (\%PSIRI $=47.22$ and 26.6, respectively) (Table S2). Raja asterias juveniles main prey were Decapoda Brachyura (\%PSIRI = 52.30) (particularly Liocarcinus spp.: \%PSIRI=36.32), while $S$. canicula juveniles had a more varied diet, composed mainly of Decapoda Natantia (\%PSIRI $=19.55)$, Decapoda Anomura $(\% \mathrm{PSIRI}=17.40)$ and Euphausiida $(\% \mathrm{PSIRI}=16.88)$ (Fig. 4; Table S2).

Juveniles of only some species preyed consistently on items other than Crustacea. These included Polychaeta and Actinopterygii (particularly G. cicerelus) in R. brachyura, Cephalopoda in S. canicula, and Sipuncula (mainly Sipunculus nudus) in $R$. asterias (Fig. 3; Table S2).

During development, Decapod Crustacean consumption became more important in almost all predator's diets (Fig. 4; Table S2) and only D. pastinaca and R. polystigma subadults and adults continued to prey consistently on Gastrosaccus spp. and Lophogaster typicus, respectively (Table S2). In $R$. brachyura; RC Raja clavata; RM Raja miraletus; RP Raja polystigma; SC Scyliorhinus canicula

miraletus subadults and adults, Decapoda consisted mainly of Natantia (particularly Solenocera membranacea) while in $S$. canicula and $R$. clavata, of Natantia, Brachyura and Anomura (Fig. 4; Table S2). Raja asterias preyed almost exclusively on Brachyura (in particular Liocarcinus spp.) throughout its life cycle (Fig. 4; Table S2).

Raja brachyura showed the clearest shift from a crustacean-based diet typical of juveniles to a piscivorous one, in subadults and adults (Actinopterygii \%PSIRI $=81.80$ and 85.51 in RB2 and RB3, respectively) (Fig. 3; Tab S2). Although Actinopterygii consumption increased in other species including $R$. clavata and $R$. asterias, this was limited to adults and comprised lower percentages (Actinopterygii \%PSIRI $=52.57$ and 44.13 , in RC3 and RA3 respectively) (Fig. 3; Table S2).

The most preyed on Actinopterygii were G. cicerelus and Glossanodon leioglossus. Gymnammodytes cicerelus reached the highest \%PSIRI values in $R$. brachyura subadults and adults (\%PSIRI $=43.68$ and 54.90, in RB2 and $\mathrm{RB} 3$ respectively), but was also consumed by $D$. pastinaca (\%PSIRI $=7.43$ and 28.74, in DP2 and DP3, respectively). 


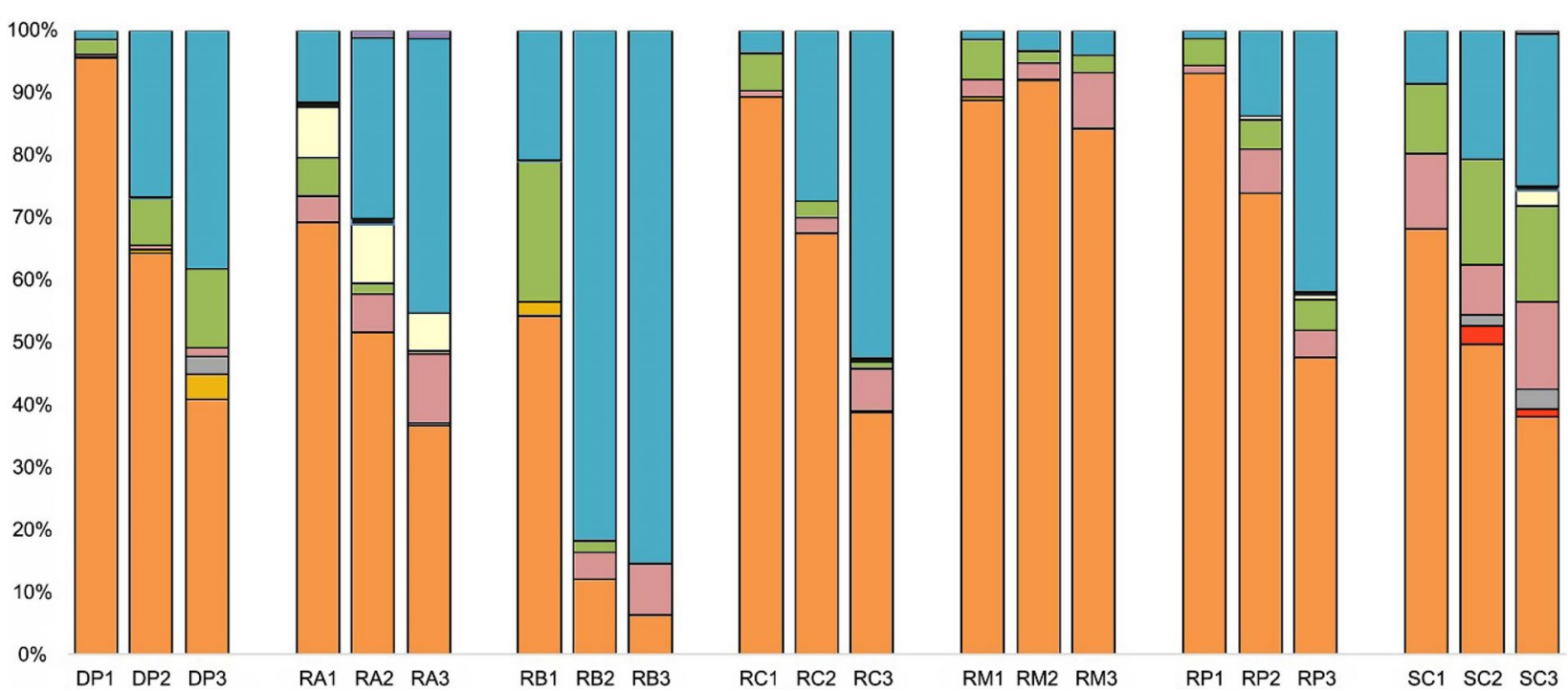

Fig. 3 Changes in the \%PSIRI (percentage Prey Specific Index of Relative Importance) of the main taxa in the diet of the size groups. Taxa with \%PSIRI $<1$ are not displayed $(\square=$ Actinopterygii; $\square=$ Cephalochordata; $\square=$ Cnidaria; $\square=$ Crustacea; $\square=$ Echinodermata; $\square=$ Elasmobranchii; $\square=$ Mollusca; $\square=$ Poly- chaeta: $\square=$ Sipuncula; $\square=$ Tunicata). DP Dasyatis pastinaca; $R A$ Raja asterias; RB Raja brachyura; $R C$ Raja clavata; RM Raja miraletus; RP Raja polystigma; SC Scyliorhinus canicula. 1=juveniles; $2=$ subadults $3=$ adults

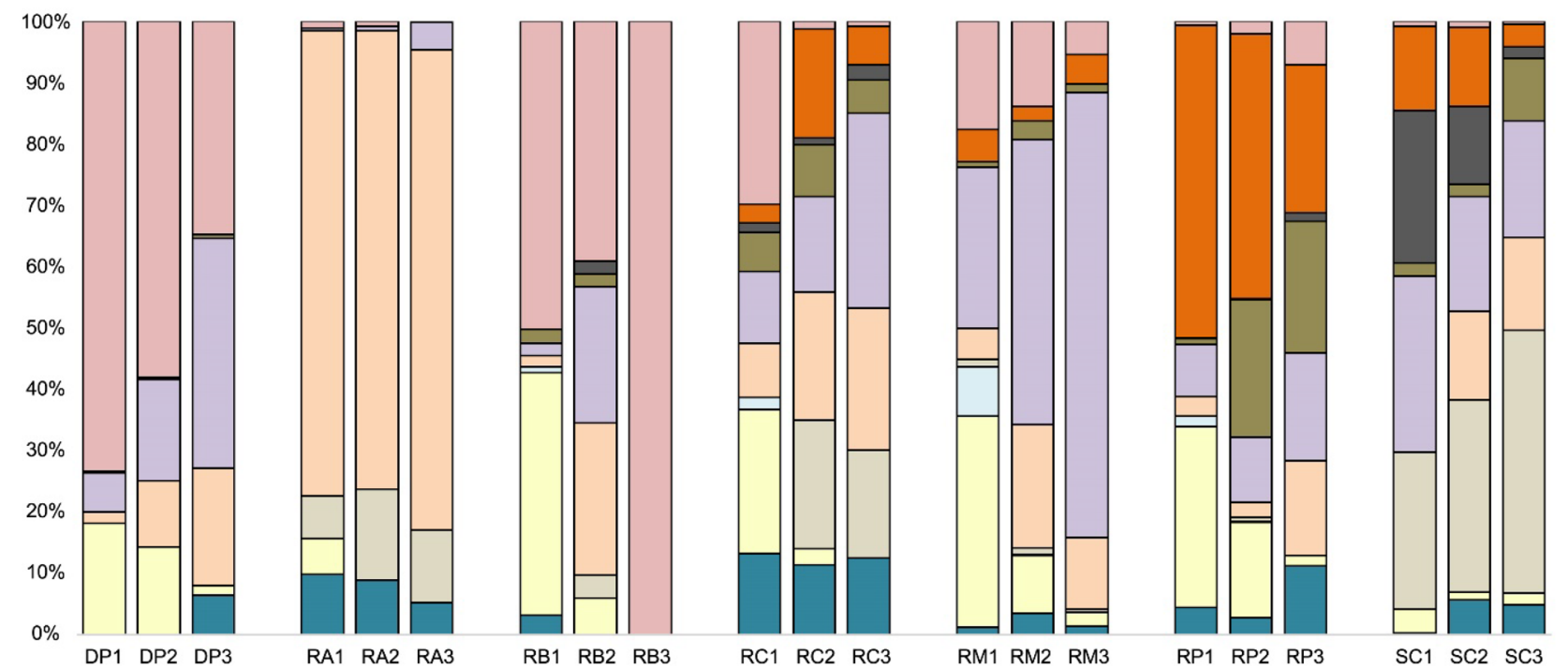

Fig. 4 Changes in the \%PSIRI (percentage Prey Specific Index of Relative Importance) of the Crustacean taxa in the diet of the size groups. Taxa with \%PSIRI $<1$ are not displayed $(\square=$ Amphipoda; $\square=$ Decapoda Anomura; $\square=$ Decapoda Brachyura; $\square=$ Copepoda; $\square=$ not identified $\quad$ Crustacea; $\square=$ Euphausiacea; $\square=$ Isop-

Glossanodon leioglossus was most important for $R$. clavata (\%PSIRI $=10.80$ and 13.93 , in $\mathrm{RC} 2$ and $\mathrm{RC} 3$, respectively) (Table S2).

Among the secondary prey, Polychaeta were found mainly in the diet of $D$. pastinaca $(\% \mathrm{PSIRI}=7.61$ and oda; $\square=$ Lophogastrida; $\square=$ Mysida; $\square=$ Decapoda Natantia). $D P$ Dasyatis pastinaca; RA Raja asterias; RB Raja brachyura; RC Raja clavata; RM Raja miraletus; RP Raja polystigma; SC Scyliorhinus canicula $1=$ juveniles; $2=$ subadults; $3=$ adults

12.68 for DP2 and DP3, respectively) and in that of $S$. canicula $(\% \mathrm{PSIRI}=17.01$ and 15.30 for SC2 and SC3, respectively), together with Mollusca (\%PSIRI $=8.04$ and 14.03 for SC2 and SC3, respectively) (Fig. 3; Table S2). Mollusca was also important for $R$. asterias subadults 
and adults (\%PSIRI = 6.19 and 10.99 for RA2 and RA3, respectively), together with Sipuncula (\%PSIRI $=9.53$ and 6.02 for RA2 and RA3, respectively) (Fig. 4; Table S2).

\section{Trophic niche breadth and trophic niche overlap among size groups}

With regard to trophic niche breadth (Levins' index, Bi), species showed two different strategies: $R$. brachyura, $R$. clavata, $R$. miraletus and $S$. canicula contracted their trophic niche with growth, while $D$. pastinaca, $R$. asterias and $R$. polystigma had a much wider food range (Table 2).

Table 4 reports the Morisita's index $\left(C_{\mathrm{h}}\right)$, SIMPER test and null model analysis values related to the groups displaying high trophic niche overlap. Generally, $C_{\mathrm{h}}$ analysis revealed low levels of overlap; slightly higher values were found only at intraspecific level. These results were also confirmed by statistical analysis (ANOSIM), the null-hypothesis of no differences among the trophic niches being rejected (global R statistic 0.38, $P<0.001$ ).

At the intra-specific level, the SIMPER test showed how high consumption of Gastrosaccus spp. was responsible for the strong trophic niche overlap among all D. pastinaca groups (Table 4). Similarly, L. typicus determined the overlap among the trophic niches in $R$. polystigma (Table 4). Decapoda Brachyura caused the niche overlap between $R$. asterias size groups, while the common consumption of Decapoda Natantia determined the high $C_{\mathrm{h}}$ values found among immature $S$. canicula and subadults, and between subadults and adults of $R$. miraletus (Table 4). Actinopterygii and Decapoda Anomura were responsible for the niche overlap between subadult and adult individuals both in $S$. canicula and $R$. clavata, while $G$. cicerelus gave the main contribution to the overlap between the same groups in $R$. brachyura (Table 4$)$.

At the inter-specific level, the high consumption of $G$. sanctus led to a strong trophic niche overlap among all groups of $D$. pastinaca, $R$. brachyura juveniles and $R$. miraletus subadults (Table 4). For the same reason, a high niche overlap was also observed between $R$. brachyura juveniles and $R$. miraletus subadults, as well as between $R$. brachyura and R.clavata juveniles (Table 4). Amphipoda were responsible for the niche overlap among $R$. miraletus juveniles and $R$. asterias and $R$. clavata juveniles. Lophogaster typicus was a common feeding resource of $R$. clavata juveniles and subadults, $S$. canicula subadults and all $R$. polystigma size groups and led to the niche overlap among these groups. Actinopterygii were primarily responsible for the trophic niche overlap between $R$. clavata adults and subadults and $S$. canicula adults (Table 4).
Table 4 SIMPER test and null model analysis for the size groups with significant Morisita's index $\left(C_{\mathrm{h}}\right)$ values

\begin{tabular}{|c|c|c|c|c|}
\hline \multirow[t]{2}{*}{ Groups } & \multirow[t]{2}{*}{$C_{\mathrm{h}}$} & \multicolumn{2}{|l|}{ SIMPER } & \multirow{2}{*}{$\begin{array}{l}\text { Null } \\
\text { model } \\
\text { analysis } \\
p \text { value }\end{array}$} \\
\hline & & Prey Items & Contribute $(\%)$ & \\
\hline DP1-DP2 & 0.99 & Gastrosaccus spp. & 44.59 & 0 \\
\hline DP1-DP3 & 0.72 & Gastrosaccus spp. & 42.06 & 0.009 \\
\hline DP2-DP3 & 0.75 & Gastrosaccus spp. & 33.37 & 0.005 \\
\hline RA1-RA2 & 0.64 & Decapoda Brachyura & 30.14 & 0.089 \\
\hline RA2-RA3 & 0.87 & Decapoda Brachyura & 28.52 & 0.001 \\
\hline RB2-RB3 & 0.89 & $\begin{array}{l}\text { Gymnammodytes } \\
\text { cicerelus }\end{array}$ & 47.11 & 0.003 \\
\hline \multirow[t]{2}{*}{$\mathrm{RC} 2-\mathrm{RC} 3$} & 0.69 & Actinopterygii & 15.24 & 0.044 \\
\hline & & Decapoda Anomura & 13.54 & \\
\hline RM2-RM3 & 0.69 & Decapoda Natantia & 22.98 & 0.05 \\
\hline RP1-RP2 & 0.98 & Lophogaster typicus & 29.08 & 0 \\
\hline RP1-RP3 & 0.71 & Lophogaster typicus & 24.94 & 0.035 \\
\hline RP2-RP3 & 0.83 & Lophogaster typicus & 22.31 & 0.007 \\
\hline SC1-SC2 & 0.82 & Decapoda Natantia & 14.89 & 0 \\
\hline \multirow[t]{2}{*}{ SC2-SC3 } & 0.77 & Actinopterygii & 15.30 & 0.014 \\
\hline & & Decapoda Anomura & 15.05 & \\
\hline RB1-DP1 & 0.92 & Gastrosaccus sanctus & 47.28 & 0.001 \\
\hline RB1-DP2 & 0.92 & Gastrosaccus sanctus & 37.19 & 0.001 \\
\hline RB1-DP3 & 0.79 & Gastrosaccus sanctus & 26.21 & 0.003 \\
\hline \multirow[t]{2}{*}{ RC1-RA1 } & 0.68 & Decapoda Brachyura & 21.21 & 0.007 \\
\hline & & Amphipoda & 19.12 & \\
\hline RC1-RB1 & 0.66 & Gastrosaccus sanctus & 23.97 & 0.005 \\
\hline RM1-RA1 & 0.68 & Amphipoda & 26.81 & 0.007 \\
\hline RM1-RC1 & 0.76 & Amphipoda & 26.43 & 0.003 \\
\hline RM2-DP1 & 0.82 & Gastrosaccus spp. & 45.80 & 0.001 \\
\hline RM2-DP2 & 0.84 & Gastrosaccus spp. & 34.73 & 0 \\
\hline RM2-DP3 & 0.83 & Gastrosaccus spp. & 19.79 & 0.003 \\
\hline RM2-RB1 & 0.91 & Gastrosaccus sanctus & 25.42 & 0 \\
\hline RM2-RC1 & 0.72 & Amphipoda & 18.90 & 0.006 \\
\hline \multirow[t]{2}{*}{ RP1-RC1 } & 0.63 & Lophogaster typicus & 23.61 & 0.004 \\
\hline & & Amphipoda & 21.85 & \\
\hline \multirow[t]{2}{*}{ RP2-RC1 } & 0.61 & Lophogaster typicus & 20.67 & 0.032 \\
\hline & & Amphipoda & 18.95 & \\
\hline RP3-RC2 & 0.71 & Lophogaster typicus & 16.24 & 0.003 \\
\hline \multirow[t]{2}{*}{$\mathrm{SC} 2-\mathrm{RC} 2$} & 0.74 & Lophogaster typicus & 14.53 & 0.005 \\
\hline & & Decapoda Anomura & 14.45 & \\
\hline \multirow[t]{3}{*}{ SC2-RC3 } & 0.63 & Actinopterygii & 17.51 & 0.006 \\
\hline & & Decapoda Natantia & 12.56 & \\
\hline & & Decapoda Anomura & 12.14 & \\
\hline \multirow[t]{2}{*}{$\mathrm{SC} 3-\mathrm{RC} 2$} & 0.72 & Decapoda Anomura & 14.83 & 0.004 \\
\hline & & Lophogaster typicus & 13.07 & \\
\hline \multirow[t]{3}{*}{ SC3-RC3 } & 0.67 & Actinopterygii & 18.61 & 0.003 \\
\hline & & Decapoda Anomura & 12.84 & \\
\hline & & Decapoda Natantia & 12.14 & \\
\hline
\end{tabular}

DP Dasyatis pastinaca; RA Raja asterias; RB Raja brachyura; $R C$ Raja clavata; RM Raja miraletus; RP Raja polystigma; SC Scyliorhinus canicula. $1=$ juveniles; 2 = subadults; $3=$ adults 


\section{Ontogenetic changes in the trophic level}

The trophic level increased with size (Table 2). With the exception of $R$. brachyura and $R$. clavata, TROPH values were always between 3 and 4 (Table 2). Raja brachyura subadults and adults, and $R$. clavata adults represented the only size groups with TROPH values higher than 4 $(\mathrm{TROPH} \pm \mathrm{SE}=4.33 \pm 0.77,4.42 \pm 0.76,4.10 \pm 0.41$ for RB2, RB3 and RC3, respectively) (Table 2). Moreover, $R$. brachyura showed the widest gap between juveniles and the other size groups $(\mathrm{TROPH} \pm \mathrm{SE}=3.46 \pm 0.53$ for $\mathrm{RB} 1)$ (Table 2). Dasyatis pastinaca juveniles fed on the lowest trophic level (TROPH $\pm \mathrm{SE}=3.27 \pm 0.44$ ) (Table 2). Based on size groups, species belonged to three functional trophic groups (Fig. 5): OA, CD, CC.

\section{Discussion}

\section{General diet description}

In this work, we analysed the feeding habits and the resource partitioning of seven elasmobranch species living on the central-western Mediterranean continental shelf. As previously reported by other authors worldwide (e.g.
Farias et al. 2006; Valls et al. 2011; Martinho et al., 2012; Šantić et al. 2012b; Barría et al. 2015, 2018), these species exhibited a high degree of full stomachs. This could be indicative of these fishes' "continuous feeder" alimentary patterns (Wetherbee et al. 2012) typical of most skates and stingrays (Jacobsen and Bennett 2013) which can also be extended to Scyliorhinus canicula. All of these elasmobranchs feed at regular intervals, resulting in a high number of prey at various stages of digestion and in a low number of empty stomachs (Wetherbee et al. 2012).

The occurrence of prey of demersal, epi- and endobenthic origin suggests that several different predatory strategies could have facilitated the strong resource partitioning observed. The batoids studied can indentify food both on and in the substrate, probably moving sediments with their pectoral fins, as also stated by Gray et al. (1997). In some cases they can move up into the water column (e.g. Morato et al. 2003). The peculiar batoid morphology (ventrally located mouth, with a close connection with the seabed) should notionally restrict food gathering to the sea-bed, suggesting that these fish would take advantage of dead prey e.g. fish, cephalopods etc. stunned by trawling (Berestovskiy 1989). While not excluding batoids (as well as $S$. canicula) from being able to take advantage of fishing discards, as demonstrated by Olaso et al. (2002),

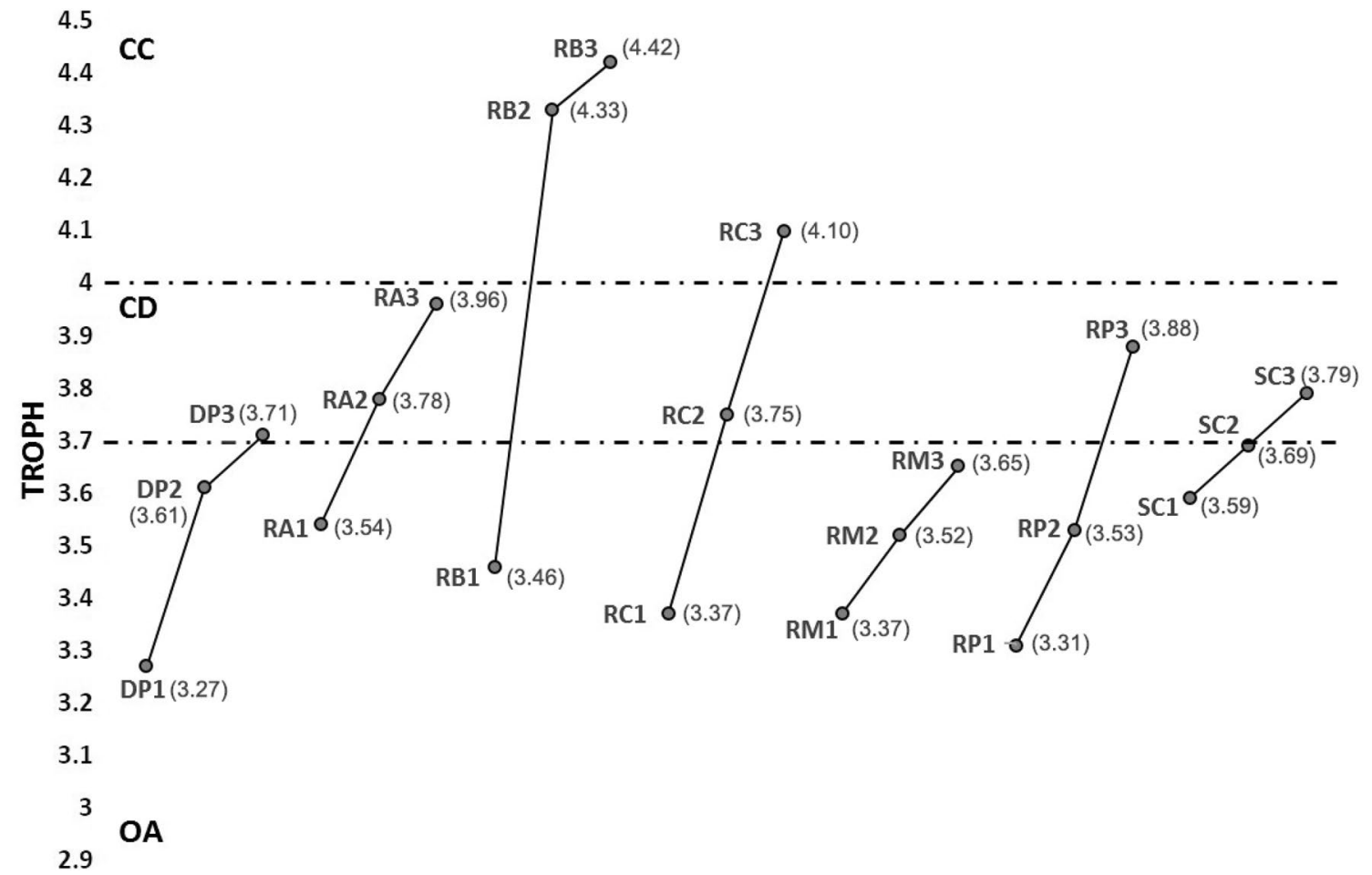

Fig. 5 Variations in the functional trophic groups during the ontogenetic development ( $C C$ carnivores with a preference for fish/cephalopods; $C D$ carnivores with a preference for crustacean decapods/fish; $O A$ omnivores with a preference for animals; in brackets the TROPH values). DP Dasyatis pastinaca; RA Raja asterias; RB Raja brachyura; RC Raja clavata; RM Raja miraletus; RP Raja polystigma; SC Scyliorhinus canicula . $1=$ juveniles; 2 = subadults; $3=$ adults 
our results seem to confirm that batoids can actively prey in the water column. This should not be surprising, given the highly active behaviour that these predators can display (e.g. swimming activity, migration movements etc.) (Hunter et al. 2005a, b). Moreover, if these batoids were only scavengers, the range of demersal by-catch prey would be wider, and their trophic niche less specialized.

Although there are some difficulties in comparing our results with existing literature mainly due to the use of heterogeneous methods over time, it emerged that feeding habits may vary markedly in relation to geographic area (Wetherbee et al. 2012), and for the most part our results agreed only partially with what has previously been reported in literature. Except for Raja brachyura, the batoid species fed mainly on Crustacea, confirming previous observations by other authors for Rajiformes and Myliobatiformes (Ebert and Bizzarro 2007, Jacobsen and Bennet 2013; Barría et al. 2015). Dasyatis pastinaca and smaller skates, like $R$. polystigma and $R$. miraletus, showed the highest levels of Crustacea in their diets. All these species had a preference for endobenthic prey, which contrasts with observations from previous studies (Smale and Cowley 1992; Ismen 2003; Yeldan et al. 2009; Saglam et al. 2010; Šantić et al. 2011; Valls et al. 2011; Kadri et al. 2014b; Barría et al. 2015; Saadaoui et al. 2015). To our knowledge, the importance of Mysida (Gastrosaccus spp.), has not previously been observed in the diet of D. pastinaca. Moreover, in a comparative analysis of the feeding and trophic levels of batoids, Jacobsen and Bennet (2013) stated that Mysida are generally prey of low importance for Dasyatidae. Raja asterias fed mainly on epibenthic Crustacea and, secondly, on demersal Actinopterygii, as described by other authors (Romanelli et al. 2007; Coll et al. 2013; Navarro et al. 2013; Barría et al. 2015). However, in Sardinian waters $R$. asterias also preyed consistently on endobenthic items, such as Sipuncula. Raja clavata has previously been reported to display a Crustacean based (Smale and Cowley 1992; Saglam and Bascinar 2008; Valls et al. 2011; Šantić et al. 2012b) or piscivorous diet (Demirhan et al. 2005; Kadri et al. 2014a). Even if $R$. clavata fed mainly on Crustacea in Sardinian waters, the consumption of burrowing prey (e.g. Lophogaster typicus) distinguished its feeding habits in this zone from previous reports by the above-mentioned authors, highlighting closer analogies with studies carried out in the Portuguese waters by Farias et al. (2006). Raja brachyura fed mainly on Actinopterygii and secondly on Crustacea, with a clear preference for burrowing prey, such as Gymnammodytes cicerelus and Gastrosaccus spp. (Catalano et al. 2007; Follesa et al. 2010). Outside the Mediterranean basin, the importance of Ammoditidae and Gastrosaccus spp. in the diet of $R$. brachyura was previously reported by Quiniou and Rabarison-Andriamirado (1979) and Farias et al. (2006). Scyliorhinus canicula had a more varied diet (Patokina and
Litvinov 2004; Olaso et al. 2005; Valls et al. 2011; Martinho et al. 2012; Barría et al. 2018), preying with similar intensity on demersal, epibenthic and endobenthic items. Our results for $S$. canicula align with results reported by Valls et al. (2011) in the Balearic continental shelf and by Martinho et al. (2012) in Portuguese waters.

\section{Trophic niche breadth and resource partitioning}

The feeding strategies observed ranged from moderate stenophagy (specialist feeders, with a narrow trophic niche breadth), as in $R$. asterias and D. pastinaca, to moderate euriphagy (generalist feeders, with a broad trophic niche breadth), as in $R$. polystigma, $R$. clavata and $S$. canicula. In general, these species with a narrower bathymetric distribution, and occupying shallower waters, showed a more specialized trophic niche with respect to those distributed in a wider depth range. Barbini et al. (2018) underlined a positive correlation between trophic and habitat niche range in batoid species, maybe due to the higher prey availability to those species that can exploit different habitats. Moreover, the levels of specialization found on the Sardinian continental shelf were higher than those reported for the same species in other areas worldwide (e.g. Patokina and Litvinov 2004; Farias et al. 2006; Martinho et al. 2012; Mnasri et al. 2012; Šantić et al. 2012a, b, 2013; Kadri et al. 2014a, b; Yemişken et al. 2018). Interestingly Valls et al. (2011) reported similar Levins' index values for $R$. clavata, $R$. miraletus and $R$. polystigma from the Balearic continental shelf.

Even if the main prey taxa were common to all predators, at lower taxonomic levels, resource partitioning was clear, and was emphasized by the multivariate analysis. This could be due to the fact that, when species coexist in the same restricted area, they modify their feeding habits to share resources and minimize competition (Heithaus 2001; Motta and Wilga 2001; Carrassón and Cartes 2002; Barría et al. 2015).

\section{Trophic level}

From a functional point of view, our study species belonged to two trophic groups: smaller skates and D. pastinaca were omnivores with a preference for animals, while the larger skates and S. canicula were carnivores with a preference for crustacean decapods and fish (sensu Stergiou and Karpouzi 2002). Sardinian specimens fed at lower trophic levels and can be considered as mesopredators (Karachle and Stergiou 2006; Navarro et al. 2013). Our TROPH values were generally close to the standardized values reported by Ebert and Bizzarro for skates (2007) and Jacobsen and Bennett (2013) for stingrays, and consistent to those values reported in other Mediterranean areas (Karachle and Stergiou 2006; Mnasri et al. 2012; Navarro et al. 2013; Barría et al. 2015, 
2018; Valls et al. 2014a, 2017). Outside the Mediterranean, these values are similar to those observed for other batoids in tropical coastal habitats (Navia et al. 2016). These results confirm batoids roles as mesopredators in marine ecosystems worldwide (Karachle and Stergiou 2006; Navarro et al. 2013). Our species trophic levels can be also compared with those of some mesopredator Actinopterygii (e.g. Lepidorhombus boscii, L. whiffiagonis, Lophius budegassa, Merluccius merluccius) and Cephalopoda (e.g. Todarodes sagittatus, Loligo forbesi), also abundant in the Mediterranean Sea (Valls et al. 2014a).

\section{Ontogenetic changes in the diet}

Shifts in the feeding habits associated with ontogenetic development are well documented in elasmobranchs (Wetherbee et al. 2012; Barbini et al. 2018). However, comprehension of the consequences of changing dietary preferences with ontogeny on resource partitioning, species interactions, trophic level and, more generally, on the ecological role of these species in marine ecosystems is still lacking (Navia et al. 2016). Our results suggest that younger individuals, with smaller mouths and fewer predatory skills, fed mainly on small benthic prey, while adults focused on larger, more mobile organisms that guarantee a higher energetic income. This change in preference could explain the increasing vacuity coefficient generally observed in the larger individuals. Bigger prey (like Actinopterygii) would ensure a higher energy intake and, consequently, would reduce the feeding frequency (Ellis et al. 1996).

Raja brachyura exhibited the clearest shift in diet, changing its alimentary spectrum from small Crustacea and Polychaeta in juveniles, to an almost entirely piscivorous diet in subadults and adults. This skate appeared to have more benthic feeding habits during ontogenetic development in Sardinian waters, than those observed by Farias et al. (2006) in Portugal. The transition to a piscivorous diet was less marked in the other species observed. Like $R$. brachyura, D. pastinaca was able to excavate the sea-bed in search of prey from its early life stages. Although with less intensity, subadults and adults of D. pastinaca continued to prey on endobenthic items. For this species, Ismen (2003) confirmed a shift to bony fish consumption amongst adults along the Turkish coast. Raja asterias, $R$. clavata and $R$. polystigma preyed on endo- and epibenthic prey during their initial life stages. Then as subadults and adults they added demersal items to their diets. Romanelli et al. (2007) described a similar trend in R. asterias diet, while Navarro et al. (2013) and Coll et al. (2013) observed no difference between the diets of the different size groups of this skate. A similar behaviour was also observed for $R$. clavata (e.g. Quiniou and Rabarison-Andriamirado 1979; Smale and Cowley 1992; Farias et al. 2006; Saglam and Bascinar
2008; Valls et al. 2011; Šantić et al. 2012b). Notably, Quiniou and Rabarison-Andriamirado (1979) stated that, in $R$. clavata, the shift to more important prey occurred at $35 \mathrm{~cm}$ TL, while Farias et al. (2006) observed a change in the diet from benthic shrimps to crabs at $45-55 \mathrm{~cm}$ TL. These measures correspond to the size range of $R$. clavata subadults in this study. Raja miraletus differed from the other batoids, feeding mainly on Crustacea during ontogenetic development. The consumption of Decapoda by $R$. miraletus increased during growth, as did that of Cephalopoda. Scyliorhinus canicula preyed on demersal, epi- and endobenthic items during its entire life cycle, increasing prey size during ontogenetic development. Olaso et al. (2005) and Valls et al. (2011) also reported similar changes in the alimentary spectrum of $S$. canicula with ontogenetic development. The first authors reported cannibalism in individuals larger than $50 \mathrm{~cm}$ TL, a behaviour not observed among Sardinian specimens.

\section{Trophic niche breadth and trophic niche overlap among size groups}

The changes in feeding strategy during ontogenetic development also influenced the trophic niche breadth of the species studied. Some species (D. pastinaca, R. asterias and R. polystigma) became more generalist, with others (R. brachyura, $R$. clavata, $R$. miraletus, $S$. canicula) becoming more specialist. The species with a narrower bathymetric distribution belonged to the first group. Barbini et al. (2018) observed a positive correlation between trophic niche breadth and size in skates $\leq 100 \mathrm{~cm}$ TL, suggesting that the increase in size could benefit individuals by allowing them to expand their prey range. Over $100 \mathrm{~cm}$ TL, the correlation became negative, maybe because larger individuals selected more energyrich prey. None of the species analysed here exceeded $100 \mathrm{~cm} \mathrm{TL}$. It is probable that the processes resulting in the observed contraction of niche breadth in those species that become more specialist during ontogenetic development are not size-related. Similarly, Barría et al. (2015) observed no positive correlation between trophic niche breadth and size in Rajiformes from the Western Mediterranean sea. In coexisting species, various mechanisms useful to minimize competition for food resources, e.g. habitat separation, prey size, predator size and morphology, species segregation, differentiation in foraging tactics, have been reported (MacPherson 1979; Karachle 2017). Among these mechanisms, a differentiation in foraging tactics could partially explain the results obtained in this study and in Barría et al. (2015).

Interspecific trophic niche overlap was limited only to a few species, especially among the smaller groups. This was due to the common consumption of recurring prey such as Gastrosaccus spp., G. cicerelus, L. typicus, and consequently 
intraspecific levels of trophic niche overlap appeared slightly higher, as also reported by Valls et al. (2011). Real competition should arise only in the event of a particular paucity of these peculiar prey items (Cartes 1998). Predation focused on particularly abundant prey during vulnerable phases of the life cycle, notably juveniles, could represent another useful adaptation to ensure higher survival rates.

\section{Ontogenetic changes in the trophic level}

Ontogenetic changes have also been found to influence the trophic level, and consequently, the predators ultimate roles in marine ecosystems (Navia et al. 2016). During their life cycles, Sardinian species occupied intermediate trophic levels typical of mesopredators. However, a more in-depth analysis showed that during ontogenetic development these species belonged to different functional trophic groups, as also stated by other authors (e.g. Navia et al. 2016; Valls et al. 2017). For those species attaining larger sizes, notably $R$. brachyura and $R$. clavata, predation on a higher number of trophic functional groups was more prevalent than in smaller species, such as $R$. miraletus or $R$. polystigma. Subadult and adult $R$. brachyura and adult $R$. clavata were, in fact, the only predators studied here that displayed trophic levels $>4$ (carnivores with a preference for fish and cephalopods), while juveniles occupied lower trophic levels, similar to those of smaller species. In particular, $R$. brachyura subadult and adult trophic levels are comparable to those of large sharks in tropical marine habitats (Navia et al. 2016). This highlights their potential role as top-predators in coastal habitats of temperate areas.

Ultimately, our study highlights the diversity of trophic roles that elasmobranchs can play during their life cycles, providing new information that can be applied to better understand the structure and the functioning of marine coastal ecosystems. Considering the vulnerability of the poorly-studied Mediterranean Ecoregion (Micheli et al. 2013) the reduction of predators over time may negatively affect the food web structure, resulting in the establishment of new interactions among species and marine ecosystem degradation (Britten et al. 2014). We anticipate that the results presented here may be applied to the development of effective management plans for these and other species.

Acknowledgements The authors would like to thank the Responsible Editor, Dr. Ewan Hunter, and the anonymous referee for their constructive comments and their kind help in improving the manuscript.

Funding Funding for this research were provided by the European Union and the Italian Ministry for Agriculture and Forestry.

\section{Compliance with ethical standards}

Conflict of interest The authors declare that they have no conflict of interest.

Ethical approval Samples were collected from monitoring programs. All applicable international, national, and/or institutional guidelines for the care and use of organisms for the study were followed.

\section{References}

Barbini SA, Sabadin DE, Lucifora LO (2018) Comparative analysis of feeding habits and dietary niche breadth in skates: the importance of body size, snout length, and depth. Rev Fish Biol Fish 28(3):625-636. https://doi.org/10.1007/s11160-018-9522-5

Barría C, Coll M, Navarro J (2015) Unravelling the ecological role and trophic relationships of uncommon and threatened elasmobranchs in the western Mediterranean Sea. Mar Ecol Prog Ser 539:225-240. https://doi.org/10.3354/meps 11494

Barría C, Navarro J, Coll M (2018) Feeding habits of four sympatric sharks in two deep-water fishery areas of the western Mediterranean Sea. Deep Sea Res Pt I. https://doi.org/10.1016/j. dsr.2018.09.010

Beddington JR (1984) The response of multispecies systems to perturbations. In: May RM (ed) Exploitation of marine communities, vol 32. Springer, New York, pp 209-226

Berestovskiy EG (1989) Feeding in the skates, Raja radiata and Raja fyllae, in the Barents and Norwegian Seas. J Ichthyol 29(8):88-96

Bizzarro JJ, Robinson HJ, Rinewalt CS, Ebert DA (2007) Comparative feeding ecology of four sympatric skate species off central California, USA. Environ Biol Fish 80:197-220. https://doi. org/10.1007/s10641-007-9241-6

Britten GL, Dowd M, Minto C, Ferretti F, Boero F, Lotze HK (2014) Predator decline leads to decreased stability in a coastal fish community. Ecol Lett 17:1518-1525. https://doi.org/10.1111/ ELE. 12354

Brown SC, Bizzarro JJ, Cailliet GM, Ebert D (2012) Breaking with tradition: redefining measures for diet description with case of study of the Aleutian skate Bathyraja aleutica (Gilbert 1896). Environ Biol Fish 95:3-20. https://doi.org/10.1007/s10641-011-9959-z

Cabral HN, Lopes M, Loeper R (2002) Trophic niche overlap between flatfishes in a nursery area on the Portuguese coast. Sci Mar 66(3):293-300

Carrassón M, Cartes JE (2002) Trophic relationships in a Mediterranean deep-sea fish community: partition of food resources, dietary overlap and connections within the benthic boundary layer. Mar Ecol Prog Ser 241:41-55. https://doi.org/10.3354/meps241041

Cartes JE (1998) Feeding strategies and partition of food resources in deep-water decapod crustaceans (400-2300 m). J Mar Biol Assoc UK 78:509-524

Catalano B, Dalù M, Scacco U, Vacchi M (2007) New biological data on Raja brachyura (Chondrichthyes, Rajidae) from around Asinara Island (NW Sardinia, Western Mediterranean). Ital J Zool 74(1):55-61. https://doi.org/10.1080/11250000600831600

Cherel Y, Ridoux V, Spitz J, Richard P (2009) Stable isotopes document the trophic structure of a deep-sea cephalopod assemblage including giant octopod and giant squid. Biol Lett 5:364-367. https://doi.org/10.1098/rsbl.2009.0024

Clarke KR, Gorley RN (2015) PRIMER v7: User Manual/Tutorial. Plymouth: PRIMER-E. http://www.primer-e.com/

Coll M, Navarro J, Palomera I (2013) Ecological role, fishing impact, and management options for the recovery of a Mediterranean 
endemic skate by means of food web models. Biol Conserv 157:108-120. https://doi.org/10.1016/j.biocon.2012.06.029

Colles A, Liow LH, Prinzing A (2009) Are specialists at risk under environmental change? Neoecological, paleoecological and phylogenetic approaches. Ecol Lett 12:849-863. https://doi.org/10.1 111/j.1461-0248.2009.01336.x

Colwell RK (2009) EstimateS: Statistical estimation of species richness in shared species from samples. Version 8.2 User's guide and application. http://purl.oclc.org/estimates/

Cortés E (1999) Standardized diet compositions and trophic levels of sharks. ICES J Mar Sci 56:707-717. https://doi.org/10.1006/ jmsc.1999.0489

Demirhan SA, Engin S, Seyhan K, Akamca E (2005) Some biological aspects of thornback ray (Raja clavata L., 1758) in the southeastern Black Sea. Turk J Fish Aquat Sci 5:75-83

Duffy JE (2002) Biodiversity and ecosystem function: the consumer connection. Oikos 99:201-219

Dulvy NK, Fowler SL, Musick JA, Cavanagh RD, Kyne M, Harrison LR, Carlson JK, Davidson LNK, Sonja V (2014) Extinction risk and conservation of the world' s sharks and rays. Elife 3:1-35. https://doi.org/10.7554/eLife.00590

Dulvy NK, Allen DJ, Ralph GM, Walls RHL (2016) The conservation status of sharks, rays and chimaeras in the Mediterranean Sea. Tech Rep. https://doi.org/10.13140/RG.2.2.22020.53129

Dulvy NK, Simpfendorfer CA, Davidson LNK, Fordham SV, Brautigam A, Sant G, Wekch DJ (2017) Challenges and priorities in Shark and Ray conservation. Curr Biol 27(11):565-572. https ://doi.org/10.1016/j.cub.2017.04.038

Ebert DA, Bizzarro JJ (2007) Standardized diet composition and trophic levels of skates (Chondrichthyes: Rajiformes: Rajoidei). Environ Biol Fish 80:221-237. https://doi.org/10.1007/s1064 1-007-9227-4

Ellis JR, Pawson MG, Shackley SE (1996) The comparative feeding ecology of six species of shark and four species of ray (Elasmobranchii) in the North-East Atlantic. J Mar Biol Assoc UK 76(1):89-106. https://doi.org/10.1017/S0025315400029039

Farias I, Figueiredo I, Moura T, Gordo LS, Neves A, Serra-Pereira B (2006) Diet comparison of four ray species (Raja clavata, Raja brachyura, Raja montagui and Leucoraja naevus) caught along the Portuguese continental shelf. Aquat Living Resour 19:105-114

Ferretti F, Worm B, Britten GL, Heithaus MR, Lotze HK (2010) Patterns and ecosystem consequences of shark declines in the ocean. Ecol Lett 13:1055-1071. https://doi.org/10.111 $1 / \mathrm{j} .1461-0248.2010 .01489 . x$

Ferry LA, Cailliet GM (1996) Sample size sufficiency and data analysis: are we characterizing and comparing diet properly? In: MacKinlay D, Shearer K (eds) Feeding ecology and nutrition in fish: proceedings of the symposium of feeding ecology and nutrition in fish. International Congress on the Biology of Fishes, San Francisco, pp 71-80

Follesa MC, Mulas A, Cabiddu S, Porcu C, Deiana AM, Cau A (2010) Diet and feeding habits of two skate species, Raja brachyura and Raja miraletus (Chondrichthyes, Rajidae) in Sardinian waters (central-western Mediterranean). Ital J Zool 77(1):5360. https://doi.org/10.1080/11250000802589600

Frodella N, Cannas R, Velonà A, Carbonara P, Farrell ED, Fiorentino F, Follesa MC, Garofalo G, Hemida F, Mancusi C, Stagioni M, Ungaro N, Serena F, Tinti F, Cariani A (2016) Population connectivity and phylogeography of the Mediterranean endemic skate Raja polystigma and evidence of its hybridization with the parapatric sibling $R$. montagui. Mar Ecol Prog Ser 554:99-113. https://doi.org/10.3354/meps 11799

Goetelli NJ, Entsminger GL (2005) EcoSim: Null model software for ecology. Version 7.72. Jericho, VT: Acquired Intelligence Inc and Kasey-Bear. http://garyentsminger.com/ecosim.htm/
Gray AE, Mulligan TJ, Hannah RW (1997) Food habits, occurrence, and population structure of the bat ray, Myliobatis californica, in Humboldt Bay, California. Environ Biol Fish 49(2):227-238. https://doi.org/10.1023/A:1007379606233

Hall SJ, Raffaelli D, Basford DJ, Robertson MR, Fryer R (1990) The feeding relationships of the larger fish species in a Scottish sea loch. J Fish Biol 37:775-791. https://doi. org/10.1111/j.1095-8649.1990.tb02541.x

Heithaus MR (2001) Predator-prey and competitive interactions between sharks (order Selachii) and dolphins (suborder Odontoceti): a review. J Zool (Lond) 253:53-68

Heithaus MR, Wirsing AJ, Dill LM (2012) The ecological importance of intact top-predator populations: a synthesis of 15 years of research in a seagrass ecosystem. Mar Freshw Res 63:1039-1050. https://doi.org/10.1071/MF12024

Hunter E, Buckley AA, Stewart C, Metcalfe JD (2005a) Migratory behavior of the thornback ray, Raja clavata in the southern North Sea. J Mar Biol Assoc UK 85(5):1095-1105. https://doi. org/10.1017/S0025315405012142

Hunter E, Buckley AA, Stewart C, Metcalfe JD (2005b) Repeated seasonal migration by a thornback ray in the southern North Sea. J Mar Biol Assoc UK 85(5):1199-1200. https://doi.org/10.1017/ S0025315405012300

Hyslop EJ (1980) Stomach contents analysis-a review of methods and their application. J Fish Biol 17:411-429. https://doi. org/10.1111/j.1095-8649.1980.tb02775.x

Irschick D, Dyer L, Sherry TW (2005) Phylogenetic methodologies for studying specialization. Oikos 110:404-408

Ismen A (2003) Age, size, reproduction and food of common stingray (Dasyatis pastinaca L., 1758) in Iskenderun Bay, the eastern Mediterranean. Fish Res 60(1):169-176. https://doi.org/10.1016/ s0165-7836(02)00058-9

Jacobsen IP, Bennett MB (2013) A comparative analysis of feeding and trophic level ecology in stingrays (Rajiformes; Myliobatoidei) and electric rays (Rajiformes: Torpedinoidei). PLoS ONE 8(8):e71348. https://doi.org/10.1371/journal.pone.0071348

Kadri H, Marouani S, Bradai MN, Bouaïn A (2014a) Diet and feeding strategy of thornback ray, Raja clavata (Chondrichthyes: Rajidae) from the Gulf of Gabes (Tunisia-Central Mediterranean Sea). J Mar Biol Assoc UK 4(7):1509-1516. https://doi.org/10.1017/ S0025315414000587

Kadri H, Marouani S, Bradai MN, Bouaïn A (2014b) Food habits of the brown ray Raja miraletus (Chondrichthyes: Rajidae) from the Gulf of Gabès (Tunisia). Mar Biol Res 10(4):426-434. https://doi. org/10.1080/17451000.2013.797583

Karachle PK (2017) Diet composition and overlap for 43 fishes in the North Aegean Sea, Greece. Acta Adriat 58(1):125-136

Karachle PK, Stergiou KI (2006) Trophic levels of north Aegean Sea fishes and comparisons with those from FishBase. In: Palomares MLD, Stergiou KI, Pauly D (eds) Fishes in Databases and Ecosystems. Fisheries Centre Research Reports 14(4). Fisheries Centre, University of British Columbia, pp 22-26

Katsanevakis S, Coll M, Piroddi C, Steenbeek J, Ben Rais Lasram F, Zenetos A, Cardoso AC (2014) Invading the Mediterranean Sea: biodiversity patterns shaped by human activities. Front Mar Sci 1:1-11. https://doi.org/10.3389/fmars.2014.00032

Kousteni V, Karachle PK, Megalofonou P, Lefkaditou E (2018) Cephalopod prey of two demersal sharks caught in the Aegean Sea (eastern Mediterranean). J Mar Biol Assoc U K 98(1):81-88. https:// doi.org/10.1017/s002531541700159x

Krebs CJ (1989) Ecological Methodology. Harper and Row, New York

Levins R (1968) Evolution in changing environments. Princeton University Press, Princeton

Liu JY, Chou LS, Chen MH (2015) Investigation of trophic level and niche partitioning of 7 cetacean species by stable isotopes, and cadmium and arsenic tissue concentrations in the western Pacific 
Ocean. Mar Pollut Bull 93:270-277. https://doi.org/10.1016/j. marpolbul.2015.01.012

MacPherson E (1979) Ecological overlap between macrourids in the Western Mediterranean Sea. Mar Biol 53(2):149-159. https://doi. org/10.1007/BF00389186

Marongiu MF, Porcu C, Bellodi A, Cannas R, Cau A, Cuccu D, Mulas A, Follesa MC (2017) Temporal dynamics of demersal chondrichthyan species in the central western Mediterranean Sea: the case study in Sardinia Island. Fish Res 193:81-94. https://doi. org/10.1016/j.fishres.2017.04.001

Martinho F, Sá C, Falcão J, Nogueira Cabral H, Pardal MA (2012) Comparative feeding ecology of two elasmobranch species, Squalus blainville and Scyliorhinus canicula, off the coast of Portugal. Fish B-NOAA 110(1):71-84

Matich P, Kiszka JJ, Mourier J, Planes S, Heithaus MR (2017) Species co-occurrence affects the trophic interactions of two juvenile reef shark species in tropical lagoon nurseries in Moorea (French Polynesia). Mar Environ Res 127:84-91. https://doi.org/10.1016/j. marenvres.2017.03.010

MEDITS (2016) MEDITS-Handbook. Version n. 8, 2016, MEDITS Working Group: $177 \mathrm{pp}$

Micheli F, Halpern BS, Walbridge S, Ciriaco S, Ferretti F, Fraschetti S, Lewison R, Nykjaer L, Rosenberg AA (2013) Cumulative human impacts on Mediterranean and Black Sea marine ecosystems: assessing current pressures and opportunities. PLoS ONE 8:e79889. https://doi.org/10.1371/journal.pone.0079889

Mnasri N, EL Kamel O, Boumaïza M, Reynaud M, Capapé C (2012) Food and feeding habits of the small-spotted catshark, Scyliorhinus canicula (Chondrichthyes: Scyliorhinidae) from the northern coast of Tunisia (central Mediterranean). Cah Biol Mar 53(1):139-150

Morato T, Sola E, Gros MP, Menezes G (2003) Diets of thornback ray (Raja clavata) and tope shark (Galeorhinus galeus) in the bottom longline fishery of the Azores northeastern Atlantic. Fish Bull 101(3):590-602

Motta PJ, Wilga CD (2001) Advances in the study of feeding behaviors, mechanisms, and mechanics of sharks. Environ Biol Fish 60:131-156. https://doi.org/10.1023/A:1007649900712

Navarro J, Coll M, Preminger M, Palomera I (2013) Feeding ecology and trophic position of a Mediterranean endemic ray: consistency between sexes, maturity stages and seasons. Environ Biol Fish 96:1315-1328. https://doi.org/10.1007/s10641-013-0109-7

Navia AF, Mejía-Falla PA, López-García J, Giraldo A, Cruz-Escalona VH (2016) How many trophic roles can elasmobranchs play in a marine tropical network? Mar Freshw Res 68:1-12. https://doi. org/10.1071/MF16161

Olaso I, Sanchez F, Rodríguez-Cabello C, Velásco F (2002) The feeding behaviour of some demersal fish species in response to artificial discarding. Sci Mar 66(3):301-311

Olaso I, Velasco F, Sánchez F, Serrano A, Rodríguez-Cabello C, Cendrero O (2005) Trophic relations of lesser-spotted catshark (Scyliorhinus canicula) and blackmouth catshark (Galeus melastomus) in the Cantabrian Sea. J Northw Atl Fish Sci 35:481-494

Orlov AM (1998) The diets and feeding habits of some deep-water benthic skates (Rajidae) in the Pacific waters off the northern Kuril islands and southeastern Kamchatka. Alaska Fish Res Bull $5(1): 1-17$

Paine RT (1969) A note on trophic complexity and community stability. Am Nat 103:91-93

Park JM, Kwak SN, Huh SH, Han IS (2017) Diets and niche overlap among nine co-occurring demersal fishes in the southern continental shelf of East/Japan Sea, Korea. Deep Sea Res Pt II 143:100-109. https://doi.org/10.1016/j.dsr2.2017.06.002

Patokina FA, Litvinov FF (2004) Food composition and distribution of demersal elasmobranches on shelf and upper slope of North-West Africa. ICES CM 2004/Session K: 19: 30 p
Paul M, Hajisamae S, Pradit S, Perngmark P, Islam R (2018) Trophic ecology of eight sympatric nemipterid fishes (Nemipteridae) in the lower part of the south China sea. Turk J Fish Aquat Sc 18:277-287. https://doi.org/10.4194/1303-2712-v18_2_07

Pauly D, Christensen V (1995) Primary production required to sustain global fisheries. Nature 374:255-257

Pauly D, Froese R, Sa-a P, Palomares M, Christensen V, Rius J (2000) TrophLab manual. ICLARM, Manila

Quiniou L, Rabarison-Andriamirado G (1979) Variations in the diet of 3 species of rays from Douarnenez Bay Finistere department France Raja montagui, Raja brachyura, Raja clavata. Cybium 7:27-39

Romanelli M, Colasante A, Scacco U, Consalvo I, Finoia MG, Vacchi M (2007) Commercial catches, reproduction and feeding habits of Raja asterias (Chondrichthyes: Rajidae) in a coastal area of the Tyrrhenian Sea (Italy, northern Mediterranean). Acta Adriat 48(1):57-71

Saadaoui A, Saidi B, Enajjar S, Bradai MN (2015) Reproductive biology of the common stingray Dasyatis pastinaca (Linnaeus, 1758) off the Gulf of Gabes (Central Mediterranean Sea). Cah Biol Mar 56(4):389-396

Saglam H, Bascinar NS (2008) Feeding ecology of thornback ray (Raja clavata Linnaeus, 1758) on the Turkish coast of the south-eastern Black Sea. Mar Biol Res 4(6):451-457. https:// doi.org/10.1080/17451000802233393

Saglam H, Kutlu S, Aydin I (2010) Diet and feeding strategy of the common stingray Dasyatis pastinaca (Linnaeus, 1758) on the Turkish coast of southeastern Black Sea. Cah Biol Marine 51(1):37-44

Sánchez-Hernández J, Vieira-Lanero R, Servia MJ, Cobo F (2011) Feeding habits of four sympatric fish species in the Iberian Peninsula: keys to understanding coexistence using prey traits. Hydrobiologia 667:119-132. https://doi.org/10.1007/s1075 0-011-0643-2

Šantić M, Paladin A, Agović A (2011) Diet of common stingray, Dasyatis pastinaca (Chondrichthyes: Dasyatidae) in the eastern Adriatic Sea. Cah Biol Mar 52(3):349-356

Šantić M, Rađa B, Pallaoro A (2012a) Feeding habits of small-spotted catshark (Scyliorhinus canicula Linnaeus, 1758) from the eastern central Adriatic Sea. Mar Biol Res 8(10):1003-1011. https://doi. org/10.1080/17451000.2012.702912

Šantić M, Rađa B, Pallaoro A (2012b) Diet and feeding strategy of thornback ray Raja clavata. J Fish Biol 81(3):1070-1084. https ://doi.org/10.1111/j.1095-8649.2012.03382.x

Šantić M, Rađa B, Pallaoro A (2013) Feeding habits of brown ray (Raja miraletus Linnaeus, 1758) from the eastern central Adriatic Sea. Mar Biol Res 9(3):301-308. https://doi.org/10.1080/17451 000.2012 .739698

Smale MJ, Cowley PD (1992) The feeding ecology of skates (Batoidea: Rajidae) off the cape south coast, South Africa. S Afr J Mar Sci 12(1):823-834. https://doi.org/10.2989/02577619209504744

Stergiou KI, Karpouzi VS (2002) Feeding habits and trophic levels of Mediterranean fish. Fish Biol Fish 11:217-254

Stevens JD, Bonfil R, Dulvy NK, Walker P (2000) The effects of fishing on sharks, rays and chimaeras (Chondrichthyans), and the implications for marine ecosystems. ICES J Mar Sci 57:476-494. https:// doi.org/10.1006/jmsc.2000.0724

Valls M, Quetglas A, Ordines F, Moranta J (2011) Feeding ecology of demersal elasmobranchs from the shelf and slope off the Balearic Sea western Mediterranean. Sci Mar 75:633-639. https://doi. org/10.3989/scimar.2011.75n4633

Valls M, Olivar MP, Fernández de Puelles ML, Molí B, Bernal A, Sweeting CJ (2014a) Trophic structure of mesopelagic fishes in the western Mediterranean based on stable isotopes of carbon and nitrogen. J Mar Syst 138:160-170. https://doi.org/10.1016/j. jmarsys.2014.04.007 
Valls M, Sweeting CJ, Olivar MP, Fernández de Puelles ML, Pasqual C, Polunin NVC, Quetglas A (2014b) Structure and dynamics of food webs in the water column on shelf and slope grounds of the western Mediterranean. J Mar Syst 138:171-181

Valls M, Rueda L, Quetglas A (2017) Feeding strategies and resource partitioning among elasmobranchs and cephalopods in Mediterranean deep-sea ecosystems. Deep-Sea Res Pt I 128:28-41. https ://doi.org/10.1016/j.dsr.2017.09.002

Wetherbee BM, Gruber SH, Cortés E (1990) Diet, feeding habits, digestion and consumption in sharks, with special reference to the lemon shark Negaprion brevirostris. In: Pratt HL, Gruber SH, Taniuchi $\mathrm{T}$ (eds) Elasmobranchs as living resources: advances in the biology, ecology, systematics, and the status of the fisheries: NOAA Technical Report NMFS, vol 90, pp 29-47

Wetherbee BM, Cortés E, Bizzarro JJ (2012) Food Consumption and Feeding Habits. In: Carrier JC, Musick JA, Heithaus MR (eds) Biology of sharks and their relatives, 2nd edn. CRC Press, Boca Raton, pp 239-264
WoRMS Editorial Board (2018) World register of marine species. http://www.marinespecies.org at VLIZ. https://doi.org/10.14284 $/ 170$

Yeldan H, Avsar D, Manasirli M (2009) Age, growth and feeding of the common stingray (Dasyatis pastinaca L., 1758) in the Cilician coastal basin, northeastern Mediterranean Sea. J Appl Ichthyol 25(S1):98-102. https://doi.org/10.1111/j.1439-0426.2008.01075.x

Yemişken E, Forero MG, Megalofonou P, Eryilmaz L, Navarro J (2018) Feeding habits of three batoids in the Levantine Sea (north-eastern Mediterranean Sea) based on stomach content and isotopic data. J Mar Biol Assoc UK 98(1):89-96. https://doi.org/10.1017/S0025 $31541700073 \mathrm{X}$

Publisher's Note Springer Nature remains neutral with regard to jurisdictional claims in published maps and institutional affiliations. 